\title{
Regionalne Inwestycje Terytorialne w subregionie płockim - realizacja
}

\section{Elżbieta Dominiak, Magdalena Wojda}

\section{STRESZCZENIE}

W artykule przedstawiono mechanizm finansowy pn. Regionalne Inwestycje Terytorialne (RIT) oraz stan realizacji ${ }^{1}$ zaplanowanych projektów w subregionie płockim. RIT to nowy instrument finansowy w ramach Regionalnego Programu Operacyjnego Województwa Mazowieckiego na lata 2014-2020, wprowadzony przez Samorząd Województwa Mazowieckiego w celu realizacji polityki rozwoju zawartej w Strategii Rozwoju Województwa Mazowieckiego do 2030 roku. Innowacyjne Mazowsze, skierowany do Obszarów Strategicznej Interwencji. Podstawą RIT jest współpraca Jednostek Samorządu Terytorialnego oparta na porozumieniu, a dokumentem wyznaczającym jego realizację są Plany Inwestycyjne dla subregionów objętych OSI problemowymi. Regionalne Inwestycje Terytorialne dla samorządów lokalnych stały się inspiracją do wspólnego planowania najważniejszych przedsięwzięć. Liderem w subregionie płockim jest Miasto Płock. Partnerzy RIT wypracowali kierunki interwencji dla rozwiązywania zidentyfikowanych problemów i potrzeb obszaru funkcjonalnego w perspektywie finansowej 2014-2020. Plan Inwestycyjny dla subregionu płockiego objętego OSI Problemowym Obszar Funkcjonalny Miasta Płocka składa się z dwóch projektów wiodących, w ramach których zostały określone projekty główne będące kluczowym elementem wiązki projektowej. Projekty te mają charakter kompleksowy i zintegrowany, i dotyczą rozbudowy systemu transportowego oraz społeczno-gospodarczej rewitalizacji obszarów zdegradowanych Obszaru Funkcjonalnego Miasta Płocka. Do realizacji zostały zaplanowane również projekty towarzyszące inwestycjom wiodącym skoncentrowane wokół problematyki szkolnictwa, rynku pracy i wykluczenia społecznego. Zrealizowane $\mathrm{w}$ ramach Regionalnych Inwestycji Terytorialnych zadania przyczyniły się do wzrostu konkurencyjności i bezpieczeństwa Obszaru Funkcjonalnego Miasta Płocka oraz poprawy jakości życia jego mieszkańców.

Słowa kluczowe: inwestycje, projekty, subregion płocki, RIT, RPOWM 2014-2020, OSI, SRWM

\section{Wstęp}

Nowe podejście do polityki spójności zaproponowane przez Komisję Europejską w perspektywie finansowej 2014-2020 znalazło odzwierciedlenie w dokumentach strategicznych województwa mazowieckiego. W województwie na poziomie regionalnym wyznaczono dwa typy Obszarów Strategicznej Interwencji (OSI): problemowe (ostrołęckosiedlecki, płocko-ciechanowski, radomski) oraz bieguny wzrostu (Obszar Metropolitalny Warszawy $)^{2}$.

\footnotetext{
${ }^{1}$ Stan na I kwartał $2019 \mathrm{r}$.

${ }^{2}$ Strategia Rozwoju Województwa Mazowieckiego do 2030 r. Innowacyjne Mazowsze.
} 
W perspektywie finansowej 2014-2020 w województwie mazowieckim funkcjonuje ZIT dla Warszawskiego Obszaru Funkcjonalnego oraz RIT-y w subregionach: płockim, siedleckim, ciechanowskim, radomskim i ostrołęckim. Inwestycje w ramach ZIT i RIT są współfinansowane z Regionalnego Programu Operacyjnego Województwa Mazowieckiego na lata 2014-2020.

RIT jako instrument finansowy, wprowadzony przez Samorząd Województwa Mazowieckiego, służy realizacji polityki rozwoju ujętej w Strategii Rozwoju Województwa Mazowieckiego do 2030 roku. Innowacyjne Mazowsze, która skierowana jest do Obszarów Strategicznej Interwencji problemowych.

Regionalne Inwestycje Terytorialne, stały się podstawą dla samorządów do podejmowania inicjatywy na rzecz wspólnego rozwoju. Wynika to również ze zmian w zakresie rozdysponowania środków z UE w ramach polityki spójności na lata 2014-2020 na poziomie regionalnym w zakresie większego wsparcia, a odnoszących się głównie do województwa mazowieckiego, które jako jedyny region w Polsce został zaliczony do regionów lepiej rozwiniętych. W polityce spójności oznacza to region przejściowy.

Liderem koordynującym prace w każdym subregionie województwa mazowieckiego jest stolica subregionu. W subregionie płockim liderem jest Miasto Płock.

\section{Przygotowania do uruchomienia RIT w subregionie płockim}

Pierwsze działania mające na celu zawiązanie partnerstwa i współpracy w ramach obszaru funkcjonalnego Płocka zostały podjęte w 2013 r. Podstawą RIT jest współpraca JST oparta na porozumieniu, które zostało podpisane pomiędzy Gminą Miasto Płock a 11 samorządami, w tym powiatami: płockim, gostynińskim i sierpeckim, gminami: Słupno, Radzanowo, Stara Biała, Nowy Duninów i Łąck oraz miastami: Gąbin, Sierpc i Wyszogród³ w 2014 r. Partnerzy podpisali również list intencyjny o współpracy w ramach Obszaru Funkcjonalnego Miasta Płocka. Pod koniec 2016 r. partnerstwo w ramach RIT zostało rozszerzone o Samorząd Województwa Mazowieckiego, co umożliwiło włączenie zadań dotyczących Wojewódzkiego Szpitala Zespolonego w Płocku (ryc.1).

Dokumentem pozwalającym na realizację RIT są Plany Inwestycyjne dla subregionów objętych OSI problemowymi. Plan Inwestycyjny dla subregionu płockiego objętego OSI problemowym Obszar Funkcjonalny Miasta Płocka został przyjęty w dniu 22 lipca 2016 r. przez Zarząd Województwa Mazowieckiego uchwałą nr 1104/166/16. W grudniu tego samego roku został on uzupełniony o projekty związane z infrastrukturą ochrony zdrowia Wojewódzkiego Szpitala Zespolonego w Płocku oraz rewitalizacją Placu Nowy Rynek w Płocku.

\footnotetext{
${ }^{3}$ Uwzględniono ze względu na kierunek ciążenia Płock-Warszawa oraz jako największy ośrodek miejski pomiędzy Płockiem i Warszawą.

${ }^{4}$ Uchwała nr 2116/209/16 Zarządu Województwa Mazowieckiego z dnia 27 grudnia 2016 r. zmieniająca uchwałę w sprawie przyjęcia dokumentu pn.: Plan Inwestycyjny dla subregionu płockiego objętego OSI problemowym Obszar Funkcjonalny Miasta Płocka.
} 
Ostatnia zmiana miała miejsce w 2017 r. i dotyczyła włączenia projektu Miasta Gminy Płock, pn. Doposażenie Płockiego Zakładu Opieki Zdrowotnej w nowoczesny sprzęt i aparature medycznq $q^{5}$.

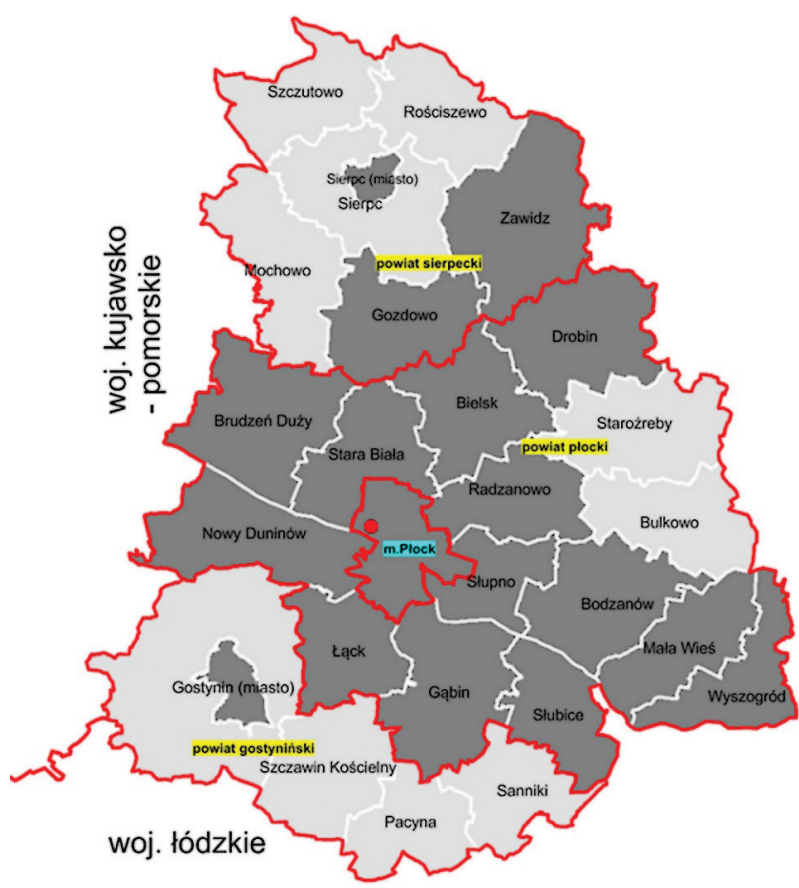

m.Plock Lider RIT

Obszar realizacji inwestycji wiodących

Ryc. 1. Obszar bezpośredniej realizacji zadań inwestycyjnych

Źródło: prezentacja Omówienie procedury realizacji Planów Inwestycyjnych, MBPR w Warszawie

\section{Przesłanki realizacji RIT w subregionie płockim}

Diagnoza Obszaru Funkcjonalnego Miasta Płocka sporządzona dla Planu Inwestycyjnego wskazała główne problemy i potrzeby tego obszaru. Należą do nich w szczególności: słaby rozwój infrastruktury, m.in. transportowej, zagrożenia wynikające z transportu ładunków niebezpiecznych, wysoki poziom emisji zanieczyszczeń, niski poziom efektywności energetycznej obiektów użyteczności publicznej, kumulacja negatywnych przesłanek w kontekście społecznym, gospodarczym i przestrzennym oraz ograniczona dostępność do wysokiej jakości usług medycznych.

${ }^{5}$ Uchwała nr 700/XXXIX/2017 Rady Miasta Płocka z dnia 28 listopada 2017 r. w sprawie zmiany Uchwały 361/XX/2016 Rady Miasta Płocka z dnia 28 czerwca 2016 r. 
Nadrzędnym problemem Obszaru jest Niedostosowanie do intensywnie zmieniajacych się warunków społeczno-gospodarczych infrastruktury technicznej warunkującej trwaty, bezpieczny i zrównoważony rozwój ${ }^{6}$.

Projekty w ramach RIT mają zintegrowany charakter i dotyczą przede wszystkim działań związanych z transportem, rewitalizacją oraz zrównoważonym rozwojem i gospodarką.

Plan Inwestycyjny dla subregionu płockiego objętego OSI Problemowym Obszar Funkcjonalny Miasta Płock $a^{7}$ składa się z dwóch projektów wiodących, w ramach których zostały określone projekty główne będące kluczowym elementem wiązki projektowej. W ramach projektu wiodącego pn. Wzrost konkurencyjności miasta Płocka i jego obszaru funkcjonalnego poprzez zrównoważony rozwój i transport - poprawa spójności i bezpieczeństwa regionu płockiego, zaplanowano również 5 inwestycji (ryc. 2). W ramach każdej z tych inwestycji, z wyjątkiem inwestycji nr 3, do realizacji przewidziano po kilka przedsięwzięć.

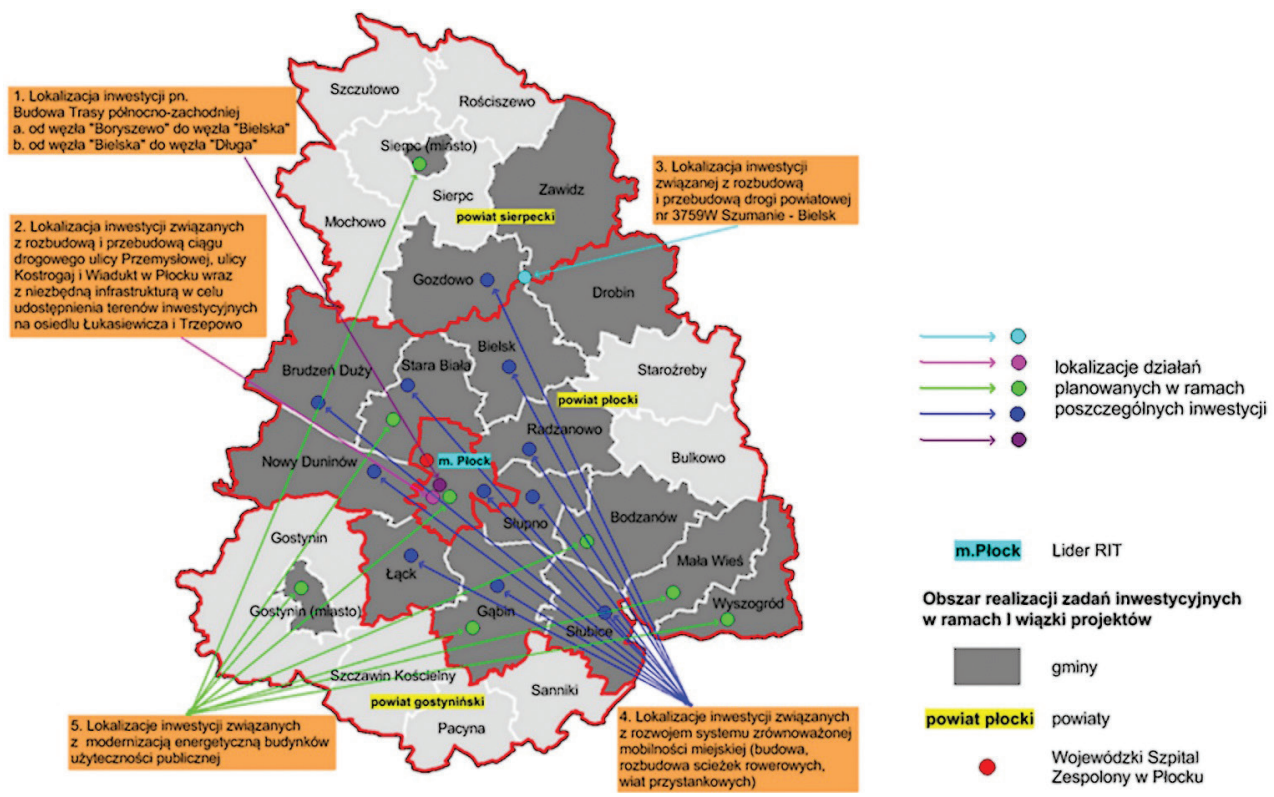

Ryc. 2. Zadania inwestycyjne w ramach I wiązki projektów

Źródło: prezentacja Omówienie procedury realizacji Planów Inwestycyjnych, MBPR w Warszawie

\footnotetext{
${ }^{6}$ Plan Inwestycyjny dla subregionu płockiego objętego OSI problemowym Obszar Funkcjonalny Miasta Płocka, s. 33. ${ }^{7}$ Uchwała nr 83/307/17 Zarządu Województwa Mazowieckiego z dnia 9 stycznia 2018 r. zmieniająca uchwałę w sprawie przyjęcia dokumentu pn.: Plan Inwestycyjny dla subregionu płockiego objętego OSI problemowym Obszar Funkcjonalny Miasta Płocka.
} 
W ramach II projektu wiodącego pn. Przywracanie funkcji społeczno-gospodarczych zdegradowanym obszarom na terenie Płocka i jego obszaru funkcjonalnego poprzez ich kompleksowa rewitalizacje zaplanowane zostały dwa projekty (ryc. 3), w tym projekt główny składający się z pięciu zadań. Poza projektami infrastrukturalnymi w ramach RIT przyjęto do realizacji projekty towarzyszące inwestycji wiodącej, tzw. projekty „miękkie”.

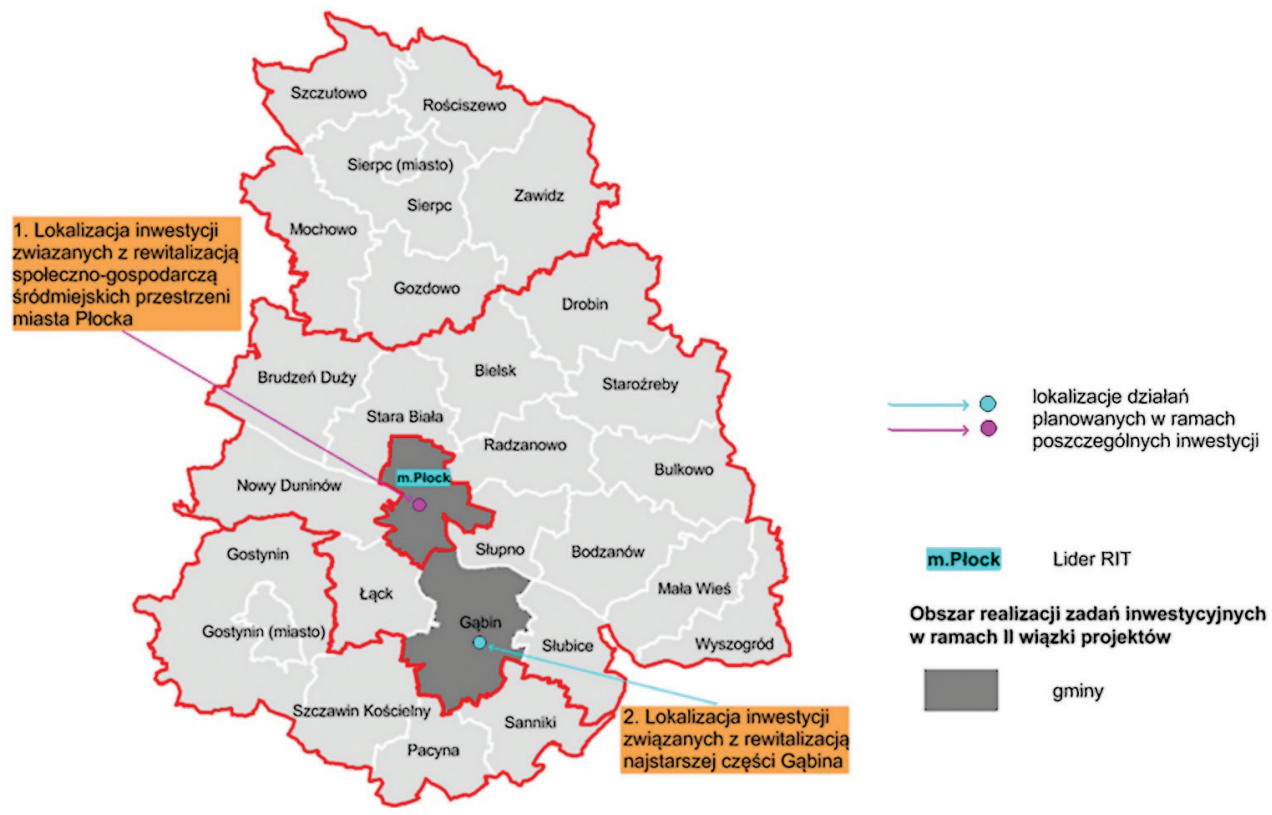

Ryc. 3. Zadania inwestycyjne w ramach II wiązki projektów

Źródło: prezentacja Omówienie procedury realizacji Planów Inwestycyjnych, MBPR w Warszawie

\section{Realizacja Planu Inwestycyjnego dla subregionu płockiego objętego OSI problemowym Obszar Funkcjonalny Miasta Płocka ${ }^{8}$}

Inwestycje wiodące określone dla Obszaru Funkcjonalnego Miasta Płocka to:

1. Wzrost konkurencyjności miasta Płocka i jego obszaru funkcjonalnego poprzez zrównoważony rozwój i sprawny transport - poprawa spójności i bezpieczeństwa regionu płockiego;

2. Przywracanie funkcji społeczno-gospodarczych zdegradowanym obszarom na terenie Płocka i jego obszaru funkcjonalnego poprzez ich kompleksowa rewitalizację.

\footnotetext{
${ }^{8}$ Stan na I kwartał 2019 r.
} 
Inwestycje realizowane w ramach I wiązki projektów dotyczą działań związanych $\mathrm{z}$ transportem, modernizacją energetyczną i ochroną zdrowia.

Działania z zakresu transportu to m.in. inwestycja pn. Budowa trasy pótnocno-zachodniej miasta Płocka - projekt główny podzielona na dwa odcinki: od węzła "Boryszewo" w ulicy Otolińskiej do węzła „Bielska” oraz od węzła „Bielska” do węzła „Długa”, realizowana w okresie od września 2016 r. do października 2018 r. Łącznie powstało ponad 9,6 km dróg, w tym drogi serwisowe, a także wybudowane zostały kanalizacja deszczowa i oświetlenie, wiadukty drogowe i kolejowy oraz trzy mosty nad rzeką Brzeźnicą. Inwestycja połączyła pierwszy odcinek obwodnicy z PKN ORLEN SA tworząc nowy ciąg drogowy, który stanowi alternatywę dla ruchu tranzytowego i transportu ciężarowego przebiegającego dotychczas przez tereny zurbanizowane drogami krajowymi nr 60 i 62.

W latach 2016-2018 rozbudowano również ciąg drogowy ulic Kostrogaj i Wiadukt oraz przebudowano ulicę Przemysłową na odcinku od ulicy Narodowych Sił Zbrojnych do ulicy Kostrogaj w ramach projektu Rozbudowa i przebudowa ciagu drogowego ulicy Przemysłowej, ulicy Kostrogaj $i$ Wiadukt w Płocku wraz z niezbędnq infrastruktura w celu udostępnienia terenów inwestycyjnych na osiedlu Łukasiewicza i Trzepowo. Inwestycja objęła przebudowę jezdni, chodników i zatok postojowych oraz budowę parkingów, dróg rowerowych i kanalizacji deszczowej. Do końca czerwca 2020 r. w ramach inwestycji na osiedlu Trzepowo powstanie około 5,6 km dróg oraz chodniki i ścieżki rowerowe wraz z oświetleniem.

W 2018 r. oddano do użytku wyremontowany fragment drogi na terenie gminy Sierpc jako realizacja zadania Rozbudowa i przebudowa drogi powiatowej nr 3759 W SzumanieBielsk. Pozostały fragment trasy będzie realizowany ${ }^{9}$.

Kolejna inwestycja pn. Rozwój systemu zrównoważonej mobilności miejskiej na terenie OFMP w ramach RIT podzielona została na trzy części. Pierwsza z nich to Rozwój infrastruktury zrównoważonej mobilności miejskiej, gdzie zrealizowano: zakup 25 autobusów o napędzie hybrydowym oraz zakup i montaż wiat przystankowych wraz z systemem DIP (Dynamiczna Informacja Pasażerska), monitoringiem i systemem powiadamiania SOS. Do realizacji pozostaje budowa pętli autobusowych wraz z systemem doładowania oraz wdrożenie systemu obszarowego sterowania ruchem. Druga to Budowa infrastruktury ścieżek i szlaków rowerowych oraz elementów towarzyszacych, w ramach której wybudowano 14,3 km dróg rowerowych na terenie miasta Płocka, w tym drogę rowerową wzdłuż ul. Wyszogrodzkiej, al. Piłsudskiego i al. Jachowicza. Ciąg ten wybudowany wzdłuż głównej arterii Płocka, łączy największe osiedla w mieście. Zbudowano również drogi rowerowe wzdłuż al. Broniewskiego i ul. Mostowej oraz w lewobrzeżnej części miasta wzdłuż ul. Dobrzykowskiej, Popłacińskiej, Portowej i Kolejowej. Planowana jest budowa ścieżek rowerowych i pieszorowerowych, na obszarze gmin powiatu płockiego (Gąbin, Łąck, Nowy Duninów i Słubice). Nowe ścieżki mają powstać wzdłuż dróg wojewódzkich nr 562 Płock - Dobrzyń n.Wisła, 574 i 575 Gąbin - Dobrzyków - Płock, 577 Gąbin - Konstantynów oraz przy drogach Czermno Wymyśle Polskie i Płock - Soczewka, a także na terenach przyległych do Jeziora Zdworskiego.

${ }^{9}$ W październiku 2018 r. Marszałek Województwa Mazowieckiego Adam Struzik i Starosta Płocki Mariusz Bieniek podpisali w tej sprawie list intencyjny. 
Trzecia część zadania to Modernizacja ciagów komunikacyjnych niezbędnych dla rozwoju systemu zrównoważonej mobilności miejskiej i obejmuje: rozbudowę ul. Łukasiewicza, przebudowę ul. Tysiąclecia, Mickiewicza i Długiej - inwestycje te zostały zrealizowane lub są w trakcie realizacji oraz budowę łącznika od ul. Czwartaków od Centrum Graniczna - realizacja tych inwestycji natomiast nie została jeszcze rozpoczęta.

W ramach I wiązki projektowej przyjęto do realizacji zadanie pn. Modernizacja energetyczna budynków użyteczności publicznej z terenu OFMP, które obejmuje pięć inwestycji dotyczących obiektów użyteczności publicznej zlokalizowanych w Płocku, Sierpcu, powiecie gostynińskim i płockim, polegające na kompleksowej modernizacji energetycznej.

Zadania przyjęte w RIT jako Infrastruktura ochrony zdrowia na terenie Obszaru Funkcjonalnego Miasta Płocka dotyczą rozbudowy infrastruktury szpitalnej wraz z zakupem nowoczesnej, specjalistycznej aparatury medycznej w Wojewódzkim Szpitalu Zespolonym w Płocku i Płockim Zakładzie Opieki Zdrowotnej Sp. z o.o.

W Wojewódzkim Szpitalu Zespolonym trwa realizacja inwestycji pn. Poprawa jakości udzielanych świadczeń dla osób z chorobami krażenia $i$ w stanach krytycznych ${ }^{10}$ oraz Zakup aparatury $i$ modernizacji infrastruktury dla AOS $i P O Z^{11}$. W ramach pierwszego zadania w nową aparaturę zostanie wyposażony m.in. Oddział Kardiologiczny, Oddział Anestezjologii i Intensywnej Terapii, Oddział Nefrologiczny, Oddział Neurologiczny, Oddział Neonatologiczny, Blok Operacyjny. Realizacja drugiego zadania to głównie modernizacja pomieszczeń Przychodni Specjalistycznych i Poradni Podstawowej Opieki Zdrowotnej wraz z rozbudową Pracowni Endoskopowej w Szpitalu.

Dla realizacji projektu pn. Utworzenie Zakładu Radioterapii w lutym 2017 r. została podpisana umowa z firmą Nu-Med na wydzierżawienie działki na budowę ośrodka z urządzeniem PET ${ }^{12}$. Inwestycja powstanie w bezpośrednim sąsiedztwie Wojewódzkiego Szpitala Zespolonego w Płocku.

Projekty Poprawa jakości udzielanych świadczeń zdrowotnych - Infrastruktura dla onkologii oraz Nowoczesny Blok Operacyjny - poprawa dostępności do świadczeń zabiegowych mające wpływ na jakość udzielanych świadczeń diagnostycznych i leczniczych, jak również lepsze standardy hospitalizacji nie zostały zrealizowane, podobnie jak inwestycja Płockiego Zakładu Opieki Zdrowotnej Sp. z o.o.

Projekty zaplanowane do realizacji w ramach II wiązki projektowej ${ }^{13}$ dotyczą rewitalizacji na rzecz odnowy przestrzeni niezbędnych dla wielostronnego rozwoju miast Płocka i Gąbina.

Kompleksowa rewitalizacja miasta Płocka w ramach zadania pn. Aktywizacja społeczno-gospodarcza zmarginalizowanych śródmiejskich przestrzeni miasta Płocka - projekt główny jest realizowana m.in. poprzez przedsięwzięcie ukierunkowane na wykorzystanie

\footnotetext{
${ }^{10}$ Umowa została podpisana w październiku 2018 r. Całkowita wartość projektu wynosi ok. 11 mln zł, w tym kwota dofinansowania ponad 8,6 mln zł. Termin zakończenie realizacji projektu zaplanowany został na wrzesień $2019 \mathrm{r}$.

${ }^{11}$ Podpisanie umowy na realizację projektu miało miejsce we wrześniu 2018 r. Całkowita wartość projektu wynosi ponad 14,4 mln, w tym kwota dofinansowania EFRR ok. 5,6 mln zł.

${ }^{12}$ https://portalplock.pl/pl/11_wiadomosci/18795_za_80_mln_zl_zbuduja_centrum_radioterapii.html

${ }^{13}$ II projekt wiodący.
} 
oraz wzmocnienie roli Płockiego Nabrzeża Wiślanego. Działania zostały podjęte jesienią 2017 r. ze środków własnych Urzędu Miasta Płocka. Umowa na dofinansowanie ${ }^{14}$ projektu została podpisana w dniu 21 września 2018 r. Realizacja polega m.in. na budowie ścieżki biegowej i rowerowej, promenady spacerowej z falochronem i wiatą sezonowa, slipu do wodowania oraz wciągania na brzeg niewielkich statków i łodzi, placów zabaw oraz miejsca do rekreacji. Elementami zrealizowanymi są: przebudowana ulica Rybaki wraz z chodnikami oraz wymieniona kanalizacja deszczowa i sanitarna. Realizacja zadania umożliwia rewitalizację społeczną tej części miasta Płocka, a obszar przejmie funkcję rekreacyjno-turystyczną.

Pozostałe projekty, zaplanowane do realizacji w ramach II wiązki projektów, tworzące z pozostałymi inwestycjami spójną i zintegrowaną całość na terenie miasta Płocka nie zostały jeszcze zrealizowane ${ }^{15}$. Rozpoczęcie realizacji projektu ${ }^{16}$ dotyczącego rewitalizacji centralnego Placu Miasta Płocka w ramach zadania pn. Ożywienie społeczno-gospodarcze przestrzeni publicznej w Płocku - Plac Nowy Rynek zostało zaplanowane na 2018 r. ${ }^{17}$ jednak z uwagi na możliwość pozyskania przez miasto Płock budynku handlowo-usługowego inwestycja została wstrzymana. Natomiast projekt pn. Ożywienie społeczno-gospodarcze przestrzeni publicznej w Płocku - Plac Obrońców Warszawy z uwagi na uwarunkowania i wymogi konkursu na projekty wpisane do Regionalnych Inwestycji Terytorialnych nie został zgłoszony o dofinansowanie ${ }^{18}$.

Projekty Modernizacja układu komunikacyjnego osiedli: Stare Miasto i Kolegialna, w tym wprowadzenie rozwiazań mechanicznych, np. windy, windy szynowe lub schody ruchome oraz Renowacja zabytkowych ${ }^{19}$ budynków i ich adaptacja (w tym wyposażenie) do petnienia nowych funkcji społeczno-edukacyjnych wraz z zagospodarowaniem terenów przyległych są powiązane z działaniami wcześniej podejmowanymi, a ich realizacja zapewni ciągłość procesu rewitalizacji. Realizacja nie została jeszcze rozpoczęta.

W 2018 r. została zakończona inwestycja ${ }^{20}$ pn. Rewitalizacja najstarszej części Gąbina ${ }^{21}$. Zakres dotyczył kompleksowej modernizacji, zmiany funkcji oraz przeznaczenia budynków zabytkowych: Stary Rynek 6 oraz dawnego Sądu Grodzkiego, ul. Płocka 7. Obiektom przywrócono wartości kulturowe i użytkowe do pełnienia funkcji publiczno-społecznych, aktywizujące lokalną społeczność.

Ważne dla rozwoju OFM Płocka, w ramach RIT są projekty towarzyszące (tzw. „miękkie") inwestycji wiodących. Zaplanowane do realizacji inwestycje koncentrują się wokół

\footnotetext{
${ }^{14}$ Dofinansowanie projektu w kwocie 23,7 mln, w tym 19,9 mln z EFRR, a 3,7 mln z budżetu państwa.

${ }^{15} \mathrm{~W}$ ramach projektu głównego II wiązki zaplanowane do realizacji w Planie Inwestycyjnym dla subregionu płockiego objętego OSI problemowym Obszar Funkcjonalny Miasta Płocka.

${ }^{16}$ Projekt pn. Ożywienie społeczno-gospodarcze przestrzeni publicznej w Płocku - Plac Nowy Rynek.

${ }^{17}$ https://warszawa.tvp.pl/38872943/plock-bedzie-nowa-koncepcja-na-nowy-rynek-remont-przesuniety

${ }^{18} \mathrm{http}: / /$ plock.wyborcza.pl/plock/7,95996,24200840,dotacji-nie-bylo-bo-do-konkursow-nie-stanelismy-przyszlosc.html; http://plock.wyborcza.pl/plock/7,35681,23690384,plac-obroncow-warszawy-bedzie-jak-nowy-za-36-mln-zl-wizualizacje.html

${ }^{19}$ Budynku przy ul. 1 Maja 3/5 wraz z przyległym terenem na cele społeczno-edukacyjne oraz budynku przy ul. Kolegialnej obecnie pełniący funkcję Urzędu Stanu Cywilnego.

${ }^{20} \mathrm{~W}$ ramach drugiej wiązki projektowej.

${ }^{21}$ Projekt uzyskał dofinansowanie $w$ kwocie ok. 3,2 $\mathrm{mln}$ zł ( $w$ tym: ok. 2,7 mln z EFRR, a ponad 0,5 mln z budżetu państwa).
} 
problemów szkolnictwa zawodowego, rozwijania kompetencji kluczowych w zakresie ICT, matematyczno-przyrodniczych, językowych, wzrostu jakości systemu doradztwa-zawodowego oraz aktywizacji społecznej i zawodowej osób zagrożonych wykluczeniem społecznym. Realizację przedsięwzięć zaplanowano na lata 2016-2021.

\section{Podsumowanie}

Projekty zawarte w Planie Inwestycyjnym dla subregionu płockiego objętego OSI problemowym Obszar Funkcjonalny Miasta Płocka są odpowiedzią na zdiagnozowane w Obszarze Funkcjonalnym Miasta Płocka problemy i potrzeby. Inwestycje są na różnym etapie realizacji, co wynika z indywidualnych uwarunkowań poszczególnych projektów. Często są również kontynuacją podjętych wcześniej działań, mających na celu rozwój przestrzenno-gospodarczy subregionu.

Najważniejszymi inwestycjami zawartymi w RIT, z punktu widzenia rozwoju Obszaru Funkcjonalnego Miasta Płocka, są projekty dotyczące budowy tras komunikacyjnych, które pozwoliły na wyprowadzenie kołowego transportu substancji niebezpiecznych poza tereny silnie zurbanizowane, a także wpłynęły na zwiększenie jego atrakcyjności dla nowych inwestycji. Ważnym elementem było również przygotowanie terenu inwestycyjnego na jednym z osiedli przemysłowych miasta.

Aspekt społeczny rozwoju subregionu został zrealizowany w postaci rewitalizacji przestrzeni publicznych zarówno w Płocku, jak i w Gąbinie oraz poprzez inwestycje w zakresie ochrony zdrowia dotyczące polepszenia jakości usług zdrowotnych, tj. zakup sprzętu i modernizację pomieszczeń.

Zrealizowane w ramach Regionalnych Inwestycji Terytorialnych zadania przyczyniły się do wzrostu konkurencyjności i bezpieczeństwa Obszaru Funkcjonalnego Miasta Płocka oraz poprawy jakości życia jego mieszkańców.

\section{Słownik skrótów}

OSI - Obszary Strategicznej Interwencji

RIT - Regionalne Inwestycje Terytorialne

ZIT - Zintegrowane Inwestycje Terytorialne

RPOWM 2014-2020 - Regionalny Program Operacyjny Województwa Mazowieckiego 2014-2020 SRWM - Strategia Rozwoju Województwa Mazowieckiego 


\section{Dokumenty i regulacje/akty prawne}

Plan Inwestycyjny dla subregionu płockiego objętego OSI problemowym Obszar Funkcjonalny Miasta Płocka - przyjęty Uchwały nr 1104/166/16 Zarządu Województwa Mazowieckiego z dnia 12 lipca 2016 r., w sprawie przyjęcia dokumentu pn.: „Plan Inwestycyjny dla subregionu płockiego objętego OSI problemowym Obszar Funkcjonalny Miasta Płocka” z późniejszymi zmianami.

Regionalny Program Operacyjny Województwa Mazowieckiego na lata 2014-2020 - zatwierdzony przez Komisję Europejską.

Strategia Rozwoju Województwa Mazowieckiego do 2030 roku. Innowacyjne Mazowsze - przyjęta Uchwałą nr 158/13 Sejmiku Województwa Mazowieckiego z dnia 28 października 2013 r.

\section{Strony internetowe}

www.funduszedlamazowsza.eu

www.mazovia.pl

www.plock.eu

http://plock.wyborcza.pl

https://warszawa.tvp.pl

https://portalplock.pl/

https://www.funduszeeuropejskie.gov.pl 


\section{Regional Territorial Investments in the Płock subregion - implementation}

\section{ABSTRACT}

The paper presents a financial mechanism called Regional Territorial Investments (RIT) and the status of the implementation of planned projects in the Płock subregion. RIT is a new financial tool in the framework of the Regional Operational Programme of the Mazovian Voivodship for 2014-2020. It was introduced by the Self-Government of the Mazovian Voivodship in order to implement the development policy contained within within the Development Strategy for the Mazovian Voivodship until 2030. Innovative Mazovia, focused on the Strategic Intervention Areas (OSI). The basis of RIT is the cooperation of Local Government Units based on an agreement and documented within the Investment Plans for problematic OSI subregions. The Regional Territorial Investments for Local Governments became an inspiration for joint planning of major projects. The leader in the subregion is the City of Plock. The RIT partners have identified the directions for interventions in order to solve the identified problems and fulfil the financial needs of the functional area in 2014-2020. The Investment Plan for the Płock subregion including the OSI functional area of the City of Płock consists of two lead projects within which the following key projects were identified. These projects are comprehensive as well as integrated, and involve the development of the transport system and the socio-economic revitalisation of the degraded areas within the functional area of the City of Plock. The following projects accompanying investment were also planned for implementation. They focus on education, labour market and social exclusion. Implemented within the framework of Regional Territorial Investments the tasks contributed to the increase of competitiveness and safety of the functional area of the City Płock and the improvement of the quality of life of its inhabitants.

Key words: investments, projects, Płock subregion, RIT, RPOWM 2014-2020, OSI, SRWM

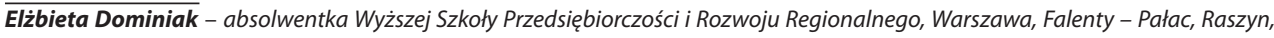
pracownik samorzq̨owy, kontakt: Mazowieckie Biuro Planowania Regionalnego w Warszawie Oddział Terenowy w Płocku, ul. Kolegialna 19, 09-402 Płock, e-mail:edominiak@mbpr.pl

Elżbieta Dominiak - graduate of the Higher School of Entrepreneurship and Regional Development, Warszawa, Falenty-Chateau, Raszyn, public administration employee, contact: Mazovian Office for Regional Planning in Warsaw, Branch office in Płock, ul. Kolegialna 19, 09-402 Płock, e-mail:edominiak@mbpr.pl
}

Magdalena Wojda - absolwentka Politechniki Warszawskiej, pracownik samorzq̨owy, kontakt: Mazowieckie Biuro Planowania Regionalnego w Warszawie Oddział Terenowy w Płocku, ul. Kolegialna 19, 09-402 Płock, e-mail: mwojda@mbpr.pl

Magdalena Wojda - graduate of the Warsaw University of Technology, public administration employee, contact: Mazovian Office for Regional Planning in Warsaw, Branch office in Płock, ul. Kolegialna 19, 09-402 Płock, e-mail: mwojda@mbpr.pl 